\title{
Geographic range shift responses to climate change by Antarctic benthos: where we should look
}

\author{
David K. A. Barnes ${ }^{1, *}$, Huw J. Griffiths ${ }^{1}$, Stefanie Kaiser ${ }^{2}$ \\ ${ }^{1}$ British Antarctic Survey, NERC, Madingley Road, Cambridge CB3 OET, UK \\ ${ }^{2}$ Biozentrum Grindel and Zoological Museum, University of Hamburg, Martin-Luther-King-Platz 3, 20146 Hamburg, Germany
}

\begin{abstract}
Toleration, adaptation, migration or extinction are the options for species making up Southern Ocean (SO) shelf biodiversity, in response to accelerating change (e.g. warming). Physiological evidence suggests few organisms may tolerate, and slow generational turn-over means fewer will adapt to, unprecedented change. To avoid extinction many organisms must migrate along linear coast, go deeper or both. There is strong evidence that such range shifts are happening, and occurred in the past, along N-S (linear) coastlines (e.g. USA), but there are no continuous shelf/slope connections to Antarctica from elsewhere. There are only 3 major linear shelves in Antarctica: Victoria Land, the Antarctic Peninsula, and the Kerguelen Plateau. Scientific effort has focused on the former two but their temperature gradient is negligible or bi-directional, so most potential for thermally-driven range shifts lies along the Kerguelen Plateau. We investigated ranges of several SO taxa (bivalve and gastropod molluscs, amphipods, ophiuroids and hexacorals), and looked for hotspots of where the geographical range limits of different species coincided. Southern Patagonia, South Georgia and Kerguelen had amongst the greatest range-limit hotspots. Shifts of SO endemics will be mainly range contractions (of northernmost limits), whilst species with ranges crossing the Polar Front (PF; the strongest jet of the Antarctic Circumpolar Current) may become 'new' SO endemics. Species with southernmost limits north of the PF should penetrate the SO, either as returning natives (expelled during glaciations) or invasive non-indigenous species. Monitoring range shifts in only a few suggested key places and taxa should give powerful insights into biodiversity responses and gauge tolerance vs. migration.
\end{abstract}

KEY WORDS: Continental shelf $\cdot$ Southern Ocean $\cdot$ Geographic limits $\cdot$ Regional warming $\cdot$ South Georgia, Kerguelen

Resale or republication not permitted without written consent of the publisher

\section{INTRODUCTION}

For the last few million years the dominant climatic pattern has been an alternation of states between long and cold ice ages (towards glacial maxima) and brief warmer inter-glacials. Environment characteristics are now rapidly changing, especially in the Antarctic Peninsula (AP) which is warming by $\sim 3.5^{\circ} \mathrm{C}$ per century (Vaughan et al. 2003). Although sea surface temperatures have increased slightly in the Bellingshausen and Scotia Seas (Meredith \& King 2005, Whitehouse et al. 2008), the main marine effect measured to date is a regional reduction in fast ice (Zwally et al. 2002). Projected climate change impacts around the AP would seem very severe given characteristics of the marine fauna such as extreme long life (see Arntz et al. 1994) and stenothermy (Peck 2005). The present article focuses on where and at what taxa to look at in order to detect range shift responses to environmental change.

Species each have thermal optima, and an upper and lower tolerances for the habitats in which they occur. Warming or cooling will change the location of their limits and optima. Species have a varying ability to alter their ranges in response to climate, with a lag phase depending on their mobility. Such dispersal may be through gametes, larvae, adult mobility or rafting by sessile adults. Typically such range shifts involve northward or southward migrations and are evident for 
fauna both extant and in the past (Roy et al. 2001, Thomas \& Lennon 1999, Beaugrand et al. 2002, Mieszkowska et al. 2007). In the UK for example, northward range shifts driven by climate change have now become very striking and a concern in the popular media (e.g. in butterflies: Clay-Jones \& Bignell 2008). Terrestrial data sets are of course more comprehensive but these too have comparability problems and unlike the SO seabed are potentially influenced by many interacting variables; e.g. biological introductions (of the study species, their predators, competitors and food plants), and land use.

Despite the considerable number and severity of direct anthropogenic impacts on biodiversity, projected climate change probably represents the greatest extinction risk to organisms in the future (Thomas et al. 2004), especially in the polar regions (Peck 2005). Most described polar biodiversity occurs in the sea, and most of that is benthic and on the continental shelf (Clarke \& Johnston 2003, Barnes et al. 2009, but see Brandt et al. 2007). We argue that the threat to survival is particularly pertinent to the rich Antarctic benthos for a number of reasons: For several million years the thermal climate of the SO has remained remarkably constant and cool (Zachos et al. 2001) giving rise to a biota with depressed upper heat tolerances (Somero \& DeVries 1967); Antarctic shelf species may be more thermally sensitive than their narrow thermal survivability envelope indicates because certain critical functions (such as predator avoidance) are even more stenothermal (Peck 2005). These traits, together with typically slow growth, long time to first reproduction and limited dispersal ability (Poulin et al. 2002), i.e. a slow generational turnover, will pose major challenges for adaptation of Antarctic shelf benthos. As the options of tolerance and adaptation in Antarctic benthos seem limited (but see Barnes \& Peck 2008), the alternative responses are migration or extinction. To avoid extinction many organisms around the AP, one of the fastest warming regions, must migrate deeper or along linear coast to reach lower temperatures.

Using fossil evidence from Seymour Island, Aronson et al. (2009) speculate there will be drastic range changes in Antarctic benthos driven by near future warming. However the fossil record around Antarctica is poorly represented in space, time and scientific effort compared with modern data, which also has the advantages of better taxonomic resolution and potential linkage to oceanographic and ecophysiological data. Range change by modern species should be most easily detected at range edges, so we used geographic information from the Southern Ocean Mollusc Database (SOMBASE) and Scientific Committee on Antarctic Research Marine Biodiversity Information Network (SCAR-MarBIN) international databases (Griffiths et al. 2003, DeBroyer \& Danis 2008) to assess where the geographic limits for Antarctic benthic marine species exist. These data has been collected and entered by the international scientific community and includes thousands of records spanning expeditions from the 1800 s to present day. We then analysed these data to look for hotspots where the geographic limits of different Antarctic species coincide (areas where many species reach the edge of their northern or southern range).

As many Antarctic species are considered to be widespread (Clarke \& Johnston 2003), their southernmost limits should abut onto the most southerly landcontinental shelf interfaces (and thus be unlikely to change and of little use to monitor). We therefore hypothesised that most southern polar marine species would have their southernmost geographic limits in the southern Weddell and Ross Seas. We expected that a key hotspot of southern limits would be the southernmost tip of South America, and that it will be important to monitor species from this area as the first potentially successful (non-indigenous) invaders of the SO. Secondly, we hypothesised that hotspots of northernmost limits would be around the boundary of the Polar Front (PF), the strongest jet of the Antarctic Circumpolar Current and generally taken to demark the edge of the SO. Under projected regional warming scenarios, our expectation is that northernmost limits will shift southwards. Finally we considered which species (identified in hotspots of southern and northern range limits) are likely to represent the best model for monitoring change.

\section{METHODS}

Study area. The current study focused on the continental shelf fauna of the South Atlantic, South Indian, South Pacific and Southern Ocean (SO) areas. The study area is approximately south of $20^{\circ} \mathrm{S}$, however South Africa and South Australia were not considered as the records for their faunas are incomplete (in SOMBASE). The northernmost boundary of the SO (our main area of interest) was defined as the Polar Front $(\mathrm{PF})$; however the PF area is complex, with dynamic eddies crossing it north and southwards, it is graduated (i.e. a zone) and also mobile (see Moore et al. 1999). These authors show that the PF can migrate 10 to $100 \mathrm{~s}$ of $\mathrm{km}$ even over short time scales (such as a decade), and will wander much more substantially with glacial-interglacial cyclicity. There are few shelf areas underlying or close to the PF zone, but those that there are, such as the Kerguelen Plateau (KP), can vary between being outside the SO (as is currently the case) to straddling the boundary or lying inside. The southernmost boundary for species in the study area was the 
edge of the Antarctica continent and, for the purposes of the current investigation, the edges of ice shelves. We appreciate that there is considerable shelf underlying some ice shelves, particularly in the Weddell and Ross Seas, and several drill-holes and remote vehicle observations have revealed a limited fauna in situ (Riddle et al. 2007). Neither of the databases used in this study contain under-shelf records, but if more extensive under-ice investigations are carried out or the geographic limit of major ice shelves retreat, many species may be recorded more southerly than the southernmost limits considered here. Furthermore, even shelf areas under ice shelves do not represent potential absolute southernmost limits, as large parts of the West Antarctica land mass would be flooded if the overlying ice sheet melts, being both below sea level and without the coastal shield of higher ground (Bamber et al. 2009).

Protocol. To identify appropriate study taxa, we evaluated the number and area coverage of records for different potential model taxa in the SOMBASE and SCARMarBIN databases (cf. Griffiths et al. 2003, DeBroyer \& Danis 2008). Each 'record' is a species reported from a georeferenced sample (such as a trawl, epi-benthic sledge, grab, core, SCUBA dive or ROV video), compiled and checked from the published literature and scientific cruise data by an international network of taxonomic editors for the wider scientific community to use. However the number of samples taken using each of these sampling methods differed in each box (defined below), which represents a source of error. It was determined that the most comprehensive records were for the shelled gastropod and bivalve molluscs, amphipod crustaceans, ophiuroid echinoderms and hexacoral cnidarians. The location of each record of each species of these model taxa is geo-referenced in each database (positions are linked to a Geographical Information System (GIS). Records for shelled gastropods ( $\mathrm{n}=9003$ records), bivalves ( $\mathrm{n}=$ 5011), amphipods $(\mathrm{n}=6406)$, ophiuroids ( $\mathrm{n}=1977)$, and hexacorals $(\mathrm{n}=1243)$, were used from the 989, 448, 829, 82 and 182 species listed in the SOMBASE and SCAR-MarBIN databases for each taxa respectively. Species lists recorded by locality (e.g. for 'South Georgia' or 'South Orkney Islands') were also examined to determine geographic range limits for cheilostome bryozoans (from SOMBASE), ascidian chordates (from P. Car- men, unpubl. data) and fish (from M. Belchier and M. Collins, unpubl. data). Thus the range of taxa considered by the current study is broadly representative of the spectrum of mobility and reproductive strategies amongst high latitude fauna (e.g. see known data for Antarctic species in www.scarmarbin.be/).

We divided the study area into a series of similar boxes, each $3 \times 3$ degrees of latitude and longitude (for more details of such methodology, see Clarke et al. 2007). We first determined the number of boxes containing records of each taxon (471 in total), and then considered geographic patterns of species range limit hotspots. We found that there were data for benthic species from 199 of the 308 (65\%) boxes over Antarctic shelf areas. The geographic range of the study and the number of boxes for which SOMBASE and SCARMarBIN contained data is shown in Fig. 1. Patterns of record intensity and richness (species number) are an important context to range limit hotspots, as potential range limit hotspots detected by this method must be a subset of sample or species richness hotspots. To show southernmost limit hotspots, we counted the number of species having their most southerly limit recorded within each box. However many of these records were

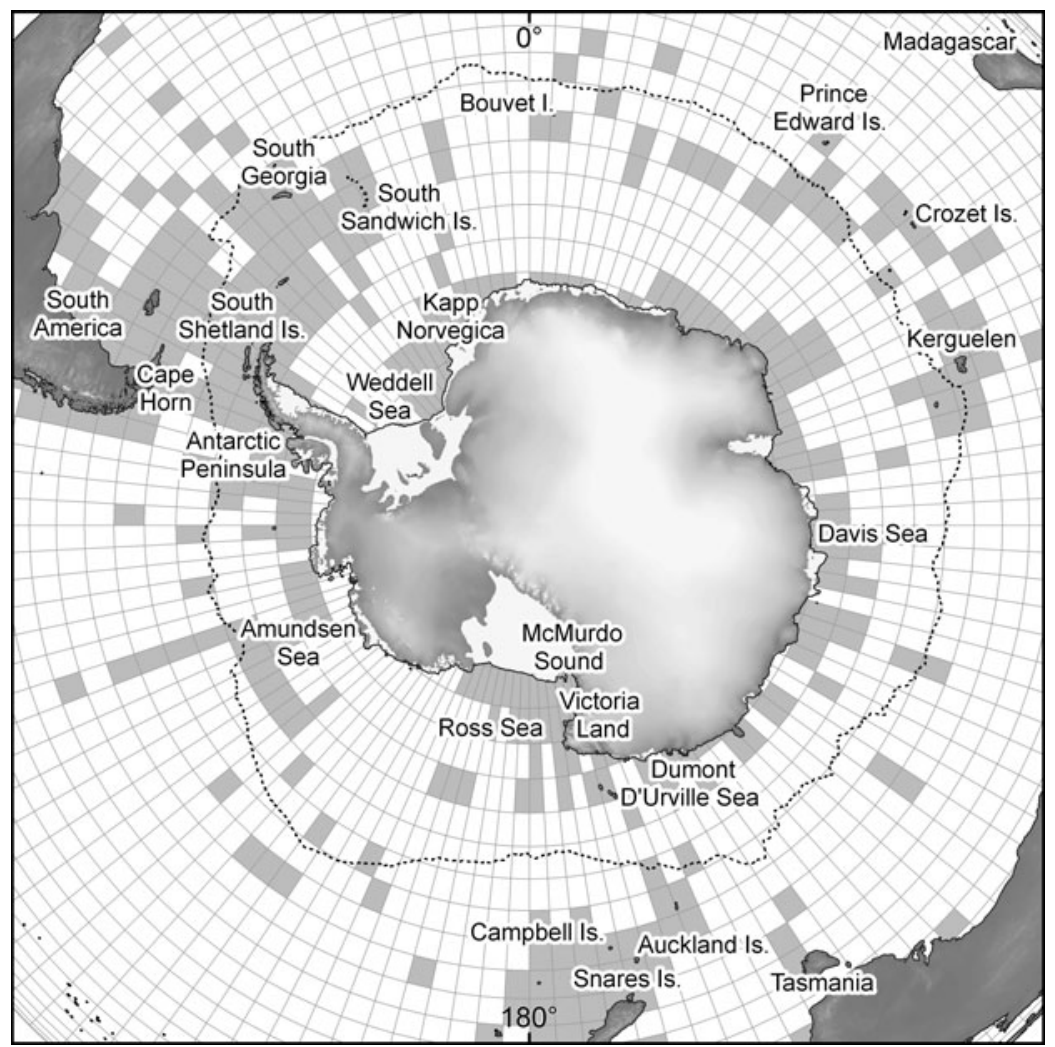

Fig. 1. Study region: Antarctica, the Southern Ocean and southern temperate areas. Grey rectangles: areas $\left(3 \times 3^{\circ}\right.$ boxes) of the study region for which data exists in the SOMBASE and SCAR-MarBIN databases for the study groups used. Dashed line: Polar Front 
of species which were only recorded in a single box; we therefore confined our data to species found in at least 3 boxes. We then repeated this process for northernmost limits, but using just the strongest $\mathrm{SO}$ datasets: those for the gastropod and bivalve molluscs.

We used the stronger data sets of shelled gastropod and bivalve species to investigate the range patterns of species found at different latitudes by dividing the study area into $10^{\circ}$ latitudinal 'bins'. The total latitudinal range of every species was measured. For each latitudinal 'bin' the number of species with particular ranges was counted (summarised into $5^{\circ}$ groups). To consider which species might be most appropriate for monitoring range changes in response to projected warming, we examined, as an example, the particular species limited at the South Georgia hotspot.

To test how effective our protocol was for detecting hotspots of range limits rather than simply reflecting sample effort, we constructed both rarefaction curves and examined residuals.

\section{RESULTS}

We found strong pattern in the intensity of records, showing a concentration of research effort around the Scotia arc, AP, Weddell and Ross Seas (Fig. 2a). Just as evident was the lack of records in the Amundsen and Davis Seas, and along the East AP; therefore any true southern limits existing in these locations will not be found by the current study. Patterns of gastropod species richness within the geographic boxes (Fig. 2b) were significantly correlated to those for the number of records (Fig. 2a: Pearson correlation $\mathrm{r}=0.726, \mathrm{p}<$ 0.001). Relationships between the number of records, species richness and range limits are shown for gastropod data in Fig. 3. In both of these plots 4 points are clearly above the $95 \%$ prediction intervals (i.e. the residuals are considerably greater than expected values). These 4 points map to the same $3 \times 3^{\circ}$ (latitude $\times$ longitude) areas; the areas highlighted as range limit hotspots in Fig. 2c,di rarefaction curves provided further support for the robustness of the hotspots identified. Rarefaction of hotspot areas showed that they accumulated range limits at least 4 times faster than other (non-hotspot) areas within the same regions. The electronic Supplement (available at www.int-res.com/ articles/suppl/m393p013_app.pdf) provides rarefaction curves for gastropods at example hot spot and non-hot spot sites showing differences in accumulation of southern limits (Fig. S1). Data on sample richness, species richness and southernmost limits for bivalve molluscs, amphipod crustaceans, ophiuroid echinoderms and hexacorals (Figs. S2 to 5) are also shown. Finally, range limit data for bivalves, amphipods, ophiuroids and hexacorals are shown together with $95 \%$ confidence and prediction intervals (Figs. S6 to S7), revealing significant range limit hotspots.

\section{Southernmost limits}

There were few southernmost limits identified in most of the boxes for which there were records, but there were hotspots found in 6 of the boxes (Fig. 2c): southernmost Cape Horn, South Georgia, Kapp Norvegica, East Kerguelen, Snares/Auckland Islands (southern New Zealand), and McMurdo Sound (southern Ross Sea). When species only present in 1 or 2 boxes were removed, far fewer boxes were found to contain recorded range limits; for example, hotspots disappeared from isolated islands such as the South Sandwich and Crozet archipelagos, and Bouvet Island (Fig. $2 d$ - the same 4 hotspots as supported by Figs. $4 \&$ S1). South Georgia, and Snares/Auckland Islands disappear from the 6 hotspots, leaving 4 key areas where southernmost gastropod limits are concentrated. However, of these southern limit hotspots it is judged that 2 are particularly important; at southernmost Cape Horn the fauna are amongst the most likely non-indigenous SO invaders in the future; distinctive examples include Calliostoma modulestum, the Fissurella limpets F. nigra, F. oriens and F. picta and Nacella limpets N. magellanica and $N$. mytilina. At the second key southern limit hotspot, the Kerguelen archipelago, there is one of the longest continuous extents of N-S shelf area, which also represents the only shelf area to cross the PF. On this basis it is argued that the fauna there has amongst the greatest potential for southward range shifts (by dispersing southwards along the Kerguelen Plateau). Example gastropod species with southern limits at Kerguelen Islands include Aforia lepta, Magarella expansa, and 3 Trophon snails (T. declinans, T. scolopax and $T$. septus). Although fewer species have geographic limits in the northwest AP and South Georgia, these are also important areas being adjacent to the only significant regions of SO warming to date (Meredith \& King 2005, Whitehouse et al. 2008).

Patterns of bivalve record intensity were approximately similar to those seen for gastropods, and included some similar hotspots; however, they differed in the presence of hotspots of sampling (no. of records) in central Chile and west AP, and their absence in Kerguelen and the Crozet Islands (see Fig. S2a-c). Richness of species showed an essentially similar pattern to sample intensity, with the exception of richness hotspots around the South Shetland Islands (Fig. S2b). In contrast to gastropod richness, the boxes with most species were southernmost Cape Horn and Snares/ Auckland Islands, which were also the only 2 strong 

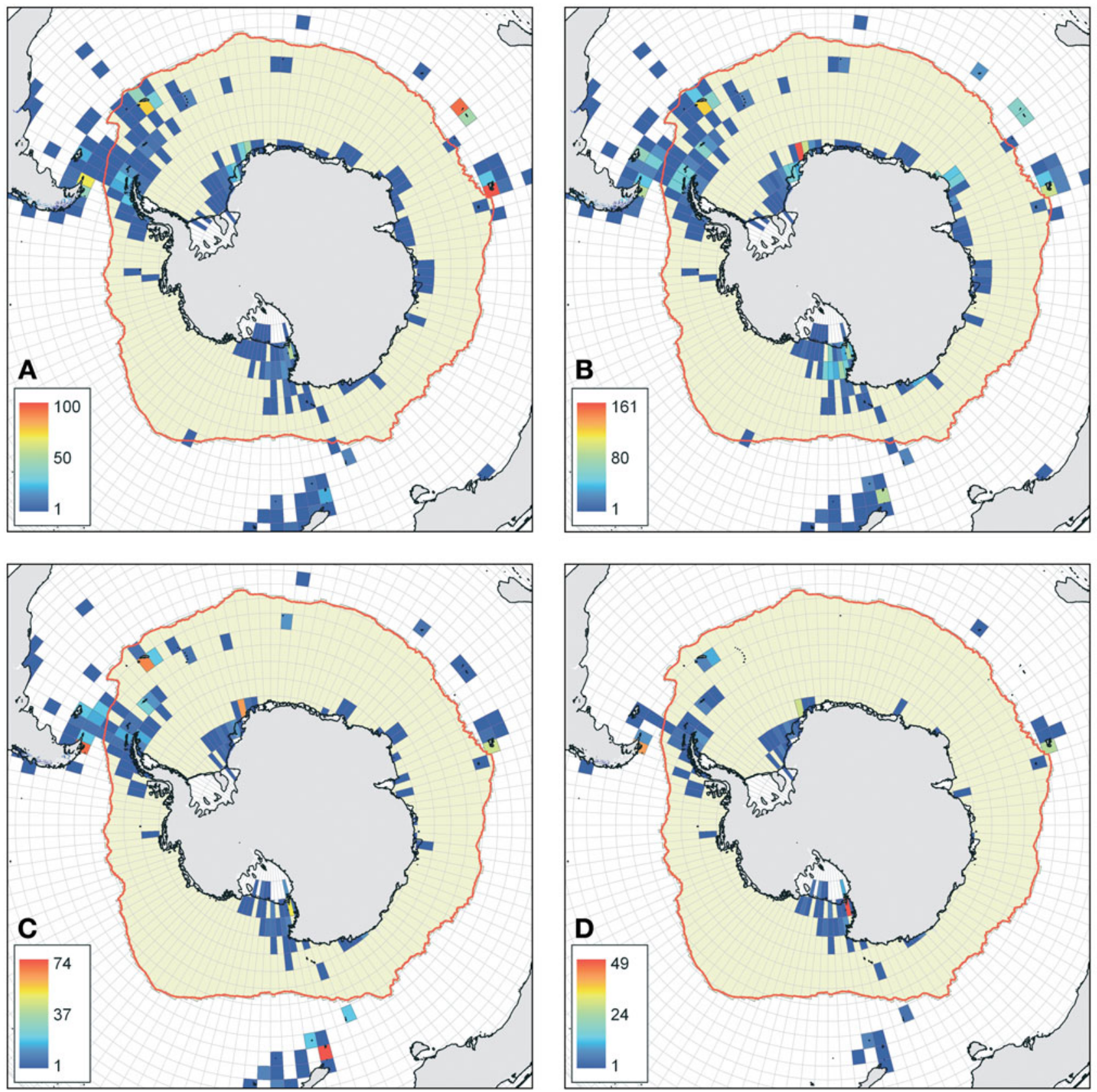

Fig. 2. Gastropod mollusc richness at high southern latitudes. (A) Numbers of records (the number of separate samples with gastropods reported), (B) numbers of species, (C) southernmost limits, (D) southernmost limits for species present in more than 2 boxes. Data from SOMBASE and SCAR-MarBIN databases

centres of southernmost range limits (Fig. S2c). However when species only found in 2 boxes or fewer were removed, 4 southern limit hotspots became apparent; southernmost Cape Horn, southern Ross Sea, Campbell Islands and the western AP (Fig. 4a - the same 4 hotspots identified by residuals in Fig. S6). At Cape Horn bivalve species at their southern limit included Chlamys patagonica, Ensis macha, Gaimardia trapesina and Mytilus edulis.
Amphipod record intensity and richness showed similar patterns, with key areas being the South Shetland Islands, South Georgia, southernmost Cape Horn and Kapp Norvegica (Fig. S3a,b). The hotspots for southernmost limits reflected these key areas, except for the additional hotspot of McMurdo Sound (Fig. S3c). With the removal of species found in fewer than 3 boxes, similar southern limit hotspots to those of the molluscs were apparent: McMurdo Sound, the 


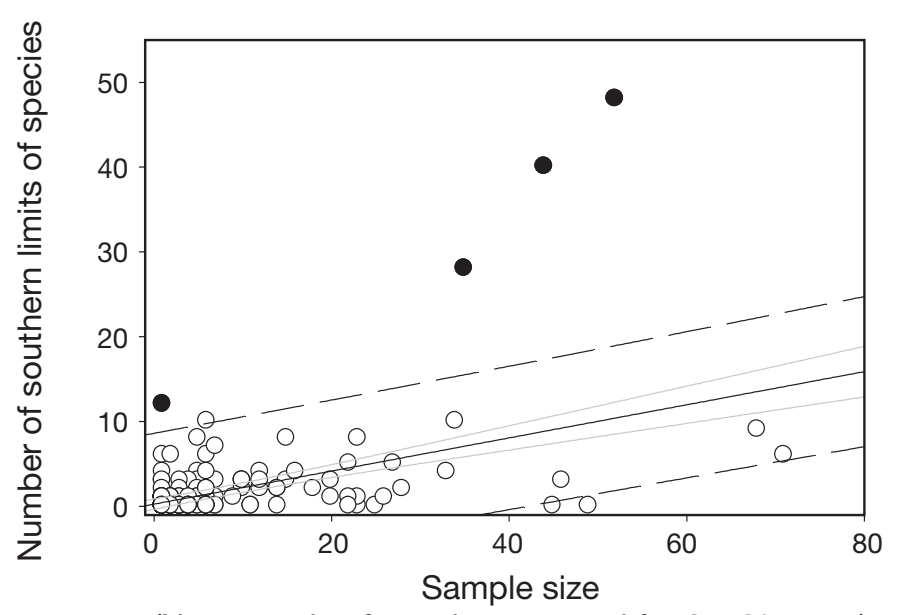

(No. records of species reported for $3 \times 3^{\circ}$ areas)

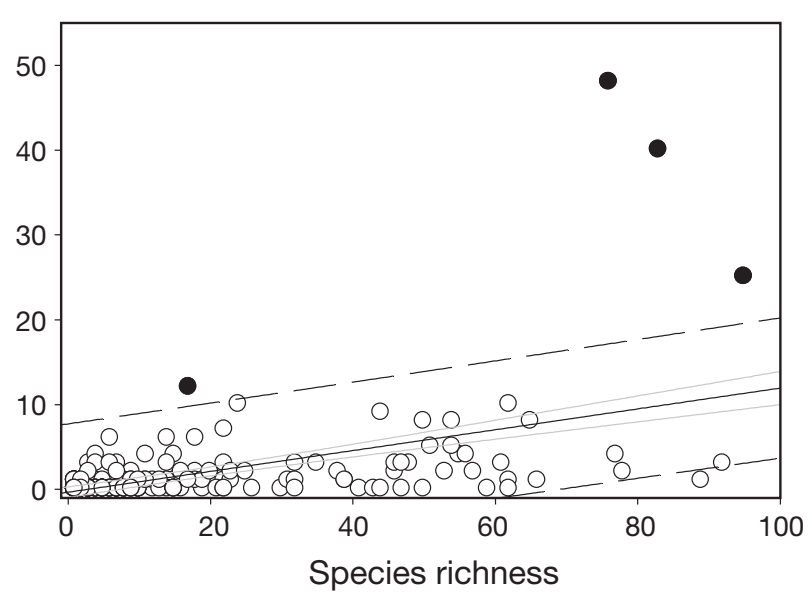

(No. species reported for $3 \times 3^{\circ}$ areas)

Fig. 3. Relationship between sample intensity, species richness and southern range limits per geographic sampling area for gastropod molluscs. Solid black line: Significant regressions, grey line: 95\% confidence interval, dashed black lines: $95 \%$ prediction lines. Filled circles: Hotspots of (southernmost) range limits; these are points with residuals above the upper $95 \%$ prediction line

western AP, southernmost Cape Horn, and Kapp Norvegica (Fig. $4 \mathrm{~b}$ - the same 4 hotspots identified by residuals in Fig. S6). Distinctive amphipod species with southernmost limits at Cape Horn include 3 Gameropsis species (G. longitarsus, G. dentifera and G. typica), 3 Gondogeneia species (G. gracilicauda, G. macrodon and G. ushuaiae) and Jassa alonsoae. At Anvers Island (western AP) a number of distinctive amphipod species reach their known southern limits, including Bovallia gigantea, Monoculodes antarcticus and 4 Oradarea species.

The patterns of record intensity and richness found in ophiuroids differed with respect to each other, and to those in other previous groups (gastropods, bivalves and amphipods). The only strong record hotspot (the number of separate samples with gastropods reported) was East Kerguelen, but many hotspots of richness were apparent around Kapp Norvegica, South Georgia, the eastern Antarctic coast (from 55 to $110^{\circ} \mathrm{E}$ ) and the Kerguelen Islands (Fig. S4a,b). These were not reflected in the southernmost limits, of which there were just 2 hotspots in the southern Weddell Sea and nearby Kapp Norvegica (Fig. S4c). Removal of species occurring in fewer than 3 boxes altered this pattern little (Fig. 4c - the same 2 hotspots identified by residuals in Fig. S6). The final group to be examined for hotspots was the hexacorals, which showed similarities in terms of record intensity and richness (especially to the gastropod and amphipod patterns). The hotspots of record intensity and richness were South Georgia, the northwest AP, south of New Zealand, and East Kerguelen. Of these South Georgia and East Kerguelen were also hotspots of southern limits, as was (to a lesser extent) southernmost Cape Horn (Fig. S5a,b). However, as shown by the bivalves, once species restricted to fewer than 3 boxes are removed, only southernmost Cape Horn was a strong southern limit hotspot (Fig. $4 \mathrm{~d}$ - the same single hotspot identified by residuals in Fig. S6). In summary, southernmost Cape Horn was the most consistent southern limit hotspot, except in the case of ophiuroids. Gastropod, bivalve and amphipod patterns had similarities: e.g. McMurdo Sound (southern Ross Sea) was also an important hotspot of southern limits. So in all 5 study taxa, there were clear range limit hotspots, all of which were identified as those in which the number of range limits was anomalously high for the level of sampling (see Figs 3, S1, S6).

\section{Northernmost limits}

We rejected analyses of northern limits for amphipods, ophiuroids and hexacorals due to the scarcity of data north of the PF, focusing instead on gastropod and bivalve molluscs. For the gastropods, South Georgia was by far the strongest hotspot of northern limits (for species which occurred in at least 3 boxes: Fig. 5a); the Crozet Islands, Kerguelen Islands, and Scotia arc were minor northern limit hotspots for gastropods. The locations of northern limits in bivalves were similar, but Prince Edward Island and the South Sandwich Islands emerged as the strongest hotspots, with Kerguelen Island and South Georgia and an area on the Patagonian shelf as minor hotspots (Fig. 5b). The northern range limit hotspots identified in Fig. 5 were supported as these were the obvious anomalies in plots of range limits by sample intensity (Fig. S7). Thus, the archipelagos of South Georgia and Kerguelen were consistently key places for northern limits of southern polar fauna, as well as having many southernmost limits of temperate fauna. 

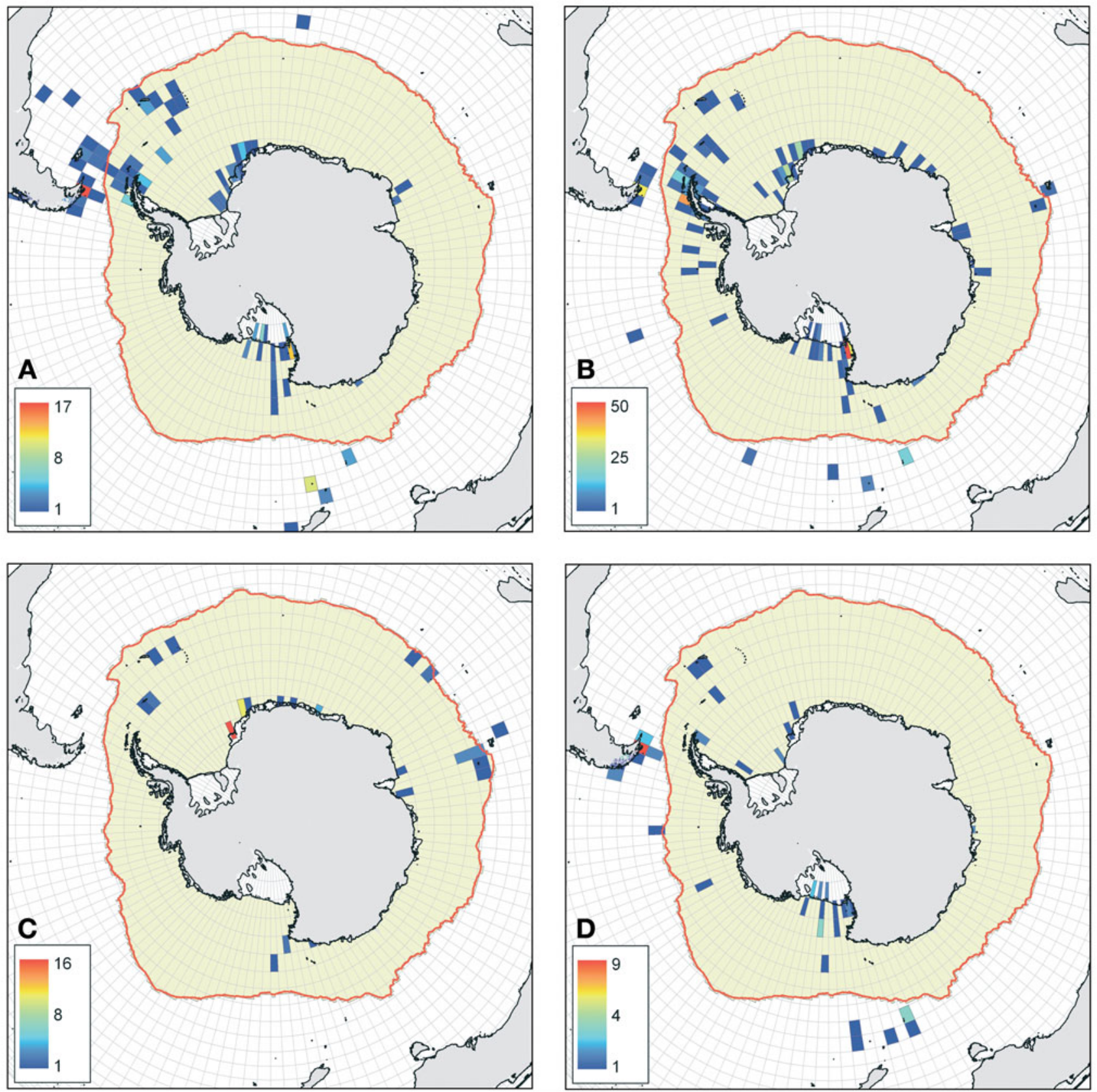

Fig. 4. Number of species at their southernmost limit at high southern latitudes (for species occurring in more than 2 boxes) by $3 \times$ $3^{\circ}$ box for (A) bivalves, (B) amphipods, (C) ophiuroids, and (D) hexacorals. Data from SOMBASE and SCAR-MarBIN databases

\section{A hotspot of range limits - South Georgia as an example}

We selected one example location, South Georgia, to investigate further because (a) analyses showed it was one of the few locations of southern and northern limits across taxa, (b) recent warming has been demonstrated, (c) it has amongst the warmest waters in the SO (Barnes et al. 2006) raising potential survivability of non-indigenous invaders, and (d) it is regularly accessed by both scientists and tourist (thereby providing increased possibilities for monitoring, but also transport opportunities for non-indigenous organisms to reach it). Although not a southern limit hotspot, Figs. 2d \& 4 show that some of the 5 study taxa are at their southernmost limit at South Georgia. Analysis of cheilostome bryozoan data in SOMBASE shows that it is the southern limit for 12 species, including Chaperiopsis acanthina, 

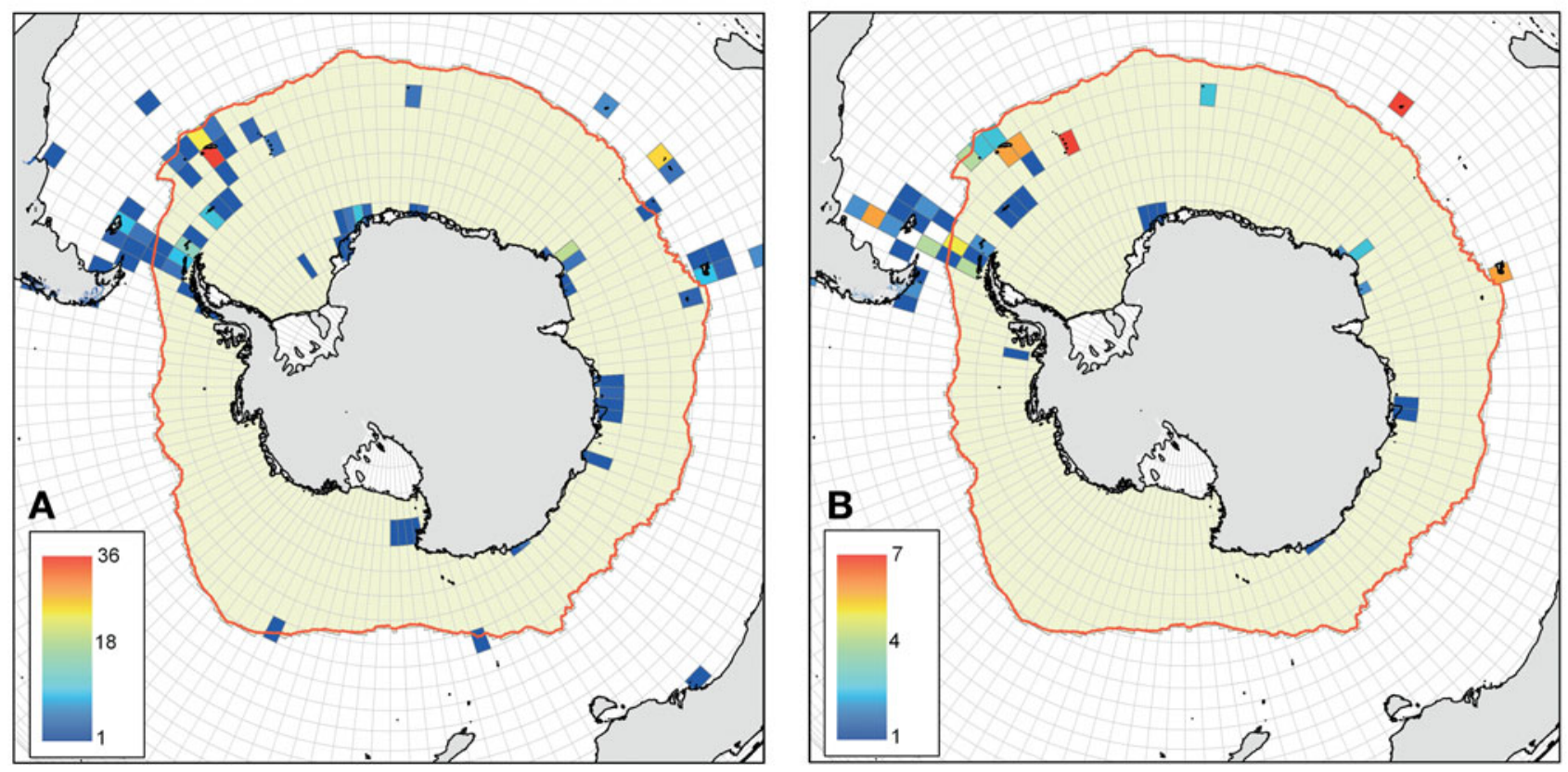

Fig. 5. Number of mollusc species at their northernmost limit at high southern latitudes (for species occurring in more than 2 boxes) by $3 \times 3^{\circ}$ box. (A) Gastropods, (B) bivalves. Data from SOMBASE and SCAR-MarBIN databases

C. orbiculata and C. rotunda as well as Electra longispina (notable for having dispersive planktonic larvae). We also found that 6 species of ascidian (e.g. Molgula malviniensis and M. setigera, P. Carmen, unpubl. data), and at least 4 species of fish (Patagonotothen guntheri, Protomyctophum choriodon, Electrona subaspera and Mancopsetta maculate; M. Collins, unpubl. data) have southern limits at South Georgia. We suggest that South Georgia is key for surveying range shift in marine biodiversity because of the density of species northernmost limits there (as opposed to southernmost). Northernmost limits are more useful in monitoring and detecting changes in species ranges scientifically, as it is easier to establish the gradual disappearance of a specific species than it is to survey for potential new arrivals (as would occur with a shift in southern range limit); this is especially true in Antarctica where confidence in complete species lists is still poor. Although only 3 ascidians have northern limits in South Georgia (Table 1), it is clear that many gastropods and bivalves do reach their northernmost limit there (Figs. 2d \& 4a), as well as additionally representing the northern edge of the range for 47 different cheilostomes (Table 1). For many species with southern or northern limits at South Georgia, database records show them to be both abundant and present in shallow shelf areas; some of these common and abundant species are particularly easy to recognise and identify, and thus we suggest that they are potentially the best model indicators to monitor (see species in bold, Table 1).

\section{Range widths with latitude}

We found that species at higher (southern) latitudes tended to have broader latitudinal ranges (Fig. 6). We observed that both gastropods and bivalves showed a similar pattern of a high number of small ranging species $\left(0-5\right.$ and $\left.5-10^{\circ}\right)$ in lower latitudes $\left(30-60^{\circ} \mathrm{S}\right)$. At higher latitudes $\left(60-80^{\circ} \mathrm{S}\right)$ the majority of species had ranges greater than $10^{\circ}$ of latitude. The bias towards small ranging species in the north of the study area may be exaggerated due to the geographic limits of the dataset: the full northern ranges of many species were not represented, and the majority of species in the dataset are those with records further south.

\section{DISCUSSION}

The response of biota to recent, rapid, regional warming is likely to include some degree of toleration, adaptation, migration and extinction. The balance of these responses will be complex and depend on local change, habitat, community, species and individual characteristics (Brooker et al. 2007, Poloczanska et al. 2008). We consider that the dominant response in the Southern Ocean (as elsewhere) will be migration; but science in the region has focused on the ability to tolerate or adapt and also, in the popular media, on extinction (Ahlstrom \& Napper 2002). Species ranges around Antarctica drastically 
Table 1. Species of benthic taxa with northernmost limits at South Georgia. Data are from SOMBASE, except ascidians courtesy of P. Carmen (unpubl. data) and fish from M. Collins (unpubl. data). Taxa in bold are those we suggest to be key species for monitoring range shift. Further details on depth ranges and thermal biology of key species are given in the Supplement

\begin{tabular}{|c|c|c|c|}
\hline Gastropods & Gastropods (cont.) & Bryozoans (cont.) & Bryozoans (cont.) \\
\hline Amauropsis georgianus & Skenella wareni ${ }^{\mathrm{a}}$ & Camptoplites retiformis & Osthimosia milleporoides \\
\hline Bela anderssoni ${ }^{\mathrm{a}}$ & Submargarita impervia ${ }^{\mathrm{a}}$ & Camptoplites tricornis & Pemmatoporella marginata \\
\hline Bela fulvicans ${ }^{a}$ & Trophon cribellum $^{\mathrm{a}}$ & Carbasea curva & Reteporella Antarctica \\
\hline Chlanidota signeyana ${ }^{\mathrm{a}}$ & Trophon distantelamellatus ${ }^{\mathrm{a}}$ & Cellaria diversa & Reteporella erugata \\
\hline Cylichna georgiana ${ }^{\mathrm{a}}$ & Trophon minutus ${ }^{\mathrm{a}}$ & Cellarinella latilaminata & Reteporella protecta \\
\hline Diaphana inflata ${ }^{a}$ & Venustatrochus georgianus $^{\mathrm{a}}$ & Cellarinella watersi & Rhamphosmittina bassleri \\
\hline Diaphana pfefferi ${ }^{\mathrm{a}}$ & & Celleporella antarctica & Smittina alticolarita \\
\hline Eatoniella aff. Caliginosa ${ }^{\mathrm{a}}$ & Bivalves & Cornucopina polymorpha & Smittina Antarctica \\
\hline Eatoniella contusa $^{\mathrm{a}}$ & $\overline{\text { Cyamium }}$ cf. willi ${ }^{\mathrm{a}}$ & Dendroperistomata projecta & Smittina incernicula \\
\hline Eatoniella glacialis ${ }^{\mathrm{a}}$ & Laternula elliptica $^{a}$ & Escharalla mamillata & Smittinella rubrilingulata \\
\hline Eatoniella subgoniostoma ${ }^{\mathrm{a}}$ & Mysella miniuscula ${ }^{\mathrm{a}}$ & Escharella watersi & Smittoidea maleata \\
\hline Kaitoa scaphandroides ${ }^{\mathrm{a}}$ & Neolepton powelli ${ }^{\mathrm{a}}$ & Escharoides praesita & \\
\hline Laevilitorina pygmaea ${ }^{\mathrm{a}}$ & Philobrya wandelensis ${ }^{\mathrm{a}}$ & Escharoides tridens & Fish \\
\hline Laevilitorina umbilicata $^{\mathrm{a}}$ & Pseudokellya georgiana ${ }^{\mathrm{a}}$ & Exochella hymenae & $\overline{\text { Aethotaxis mytopteryx }}$ \\
\hline Lorabela pelseneeri $^{\mathrm{a}}$ & Tindaria antarctica ${ }^{a}$ & Fenestrulina cervicornix & Artededraco miras \\
\hline Margarella achilles ${ }^{\mathrm{a}}$ & & Fenestrulina crystallina & Bathydraco joannae \\
\hline Margarella steineni ${ }^{\mathrm{a}}$ & Ascidians & Fenestrulina rugula & Chaenocephalus aceratus \\
\hline Margarella tropidophoroides ${ }^{\mathrm{a}}$ & 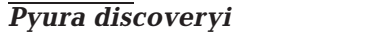 & Filaguria spatulata & Champsocephalus gunnari \\
\hline Nacella concinna ${ }^{\mathrm{a}}$ & Styela insuosa & Himantozoum antarcticum & Gobionotothen gibberifrons \\
\hline Nacella polaris $^{\mathrm{a}}$ & Aplidium radiatum & Hippadanella inerma & Lepidonotothen larseni \\
\hline Nothoadmete antarctica ${ }^{\mathrm{a}}$ & & Isoschizoporella secunda & Lepidonotothen nudifrons \\
\hline Onoba anderssoni ${ }^{\mathrm{a}}$ & Bryozoans & Klugeflustra Antarctica & Lepidonotothen squamifrons \\
\hline Onoba cf. gelida ${ }^{\mathrm{a}}$ & $\overline{\text { Adeloscopora jeqolqa }}$ & Klugarella Antarctica & Notothenia rossii \\
\hline Onoba filostria ${ }^{\mathrm{a}}$ & Aimulosia antarctica & Lageneschara lyrulata & Parachaenichthys georgianus \\
\hline Onoba turqueti ${ }^{\mathrm{a}}$ & Amphiblestrum familiaris & Larvapora mawsoni & Pleuragramma antarcticum \\
\hline Philine gibba ${ }^{\mathrm{a}}$ & Arachnopusia decepiens & Nematoflustra flagellate & Pseudochaenichthys georgianius \\
\hline Photinula steineni ${ }^{\mathrm{a}}$ & Buffonellaria frigida & Notoplites antarcticus & Trematomus hansoni \\
\hline Pleurotomella bathybia ${ }^{\mathrm{a}}$ & Buffonellodes antarctica & Notoplites drygalski & \\
\hline Proneptunea fenestrata ${ }^{\mathrm{a}}$ & Camptoplites giganteus & Notoplites tenuis & ${ }^{\mathrm{a}}$ Taxa used in Fig. 6 \\
\hline
\end{tabular}

changed in response to varying climate in the past, and Aronson et al. (2009) suggest that they will alter radically in the near future. The current study is the first to quantify southern and northern range limits, and geographic hotspots of these limits, and to identify which modern taxa have the best geographic information. We consider there is an urgent need to focus survey effort in the most appropriate areas and taxa in order to most rapidly detect responses to warming in Antarctica's rich biodiversity. We accept that there is considerable bias in Antarctica data (sample size varies considerably between areas, and some range limit hotspots are close to research stations); but both residuals of record intensity versus range limits (Fig. 3, S6) and rarefaction curves (Fig. S1) show hotspot independence from sampling. Error margins will be considerable, perhaps for decades: location and depths of recent and planned scientific cruises, coupled with the long lag time for specieslevel identifications, means observed patterns are unlikely to be significantly updated in the near future. Given the thermal sensitivity experimentally derived for some benthos (Peck 2005) and the rapid temperature change in the region (Vaughan et al. 2003), we suggest that it is important to start monitor- ing now rather than waiting for spatial coverage of records to approach that in places such as the North Atlantic.

Models have been developed for a few temperate species to test predicted responses of species to climate change with some success (Lima et al. 2007). The same authors show that where the model failed to predict a lack of northward range shift, there was a gap of unsuitable habitat; again this highlights the complexity of response, and the importance of ground-truthing. The most documented response to climate change has been either a northward or southward range shift (Thomas \& Lennon 1999, Roy et al. 2001, Beaugrand et al. 2002), but Antarctic continental shelves and slopes are isolated from elsewhere. Victoria Land (VL), AP, and the Kerguelen Plateau (KP) are the only major linear shelves around Antarctica (Fig. 7a). The temperature gradient along VL and AP is negligible or bidirectional (Fig. 7b), so the most potential for thermally-driven range shifts lies along the KP.

Marine warming has recently been detected in the AP and Scotia arc (Meredith \& King 2005, Whitehouse et al. 2008), so we argue that the immediate priorities should be the generation of range limit baselines, and the identification of hotspots and model taxa. We hypo- 
thesised above that hotspots of southern range limits for Antarctic benthos would be in the southern Weddell and Ross Seas, and this was broadly true for the taxa studied (Figs. $2 \& 4$ ). These areas are amongst the most southerly of any shelf areas; however, other than under-ice shelf environments of the Weddell and Ross
Seas, there is no possibility for southward range shift and thus escape from future warming is limited to migration to deeper waters. Cape Horn was the strongest southern range limit hotspot in our data for temperate species (with the exception of ophiuroids, due to few records in SCAR-MarBIN; this probably
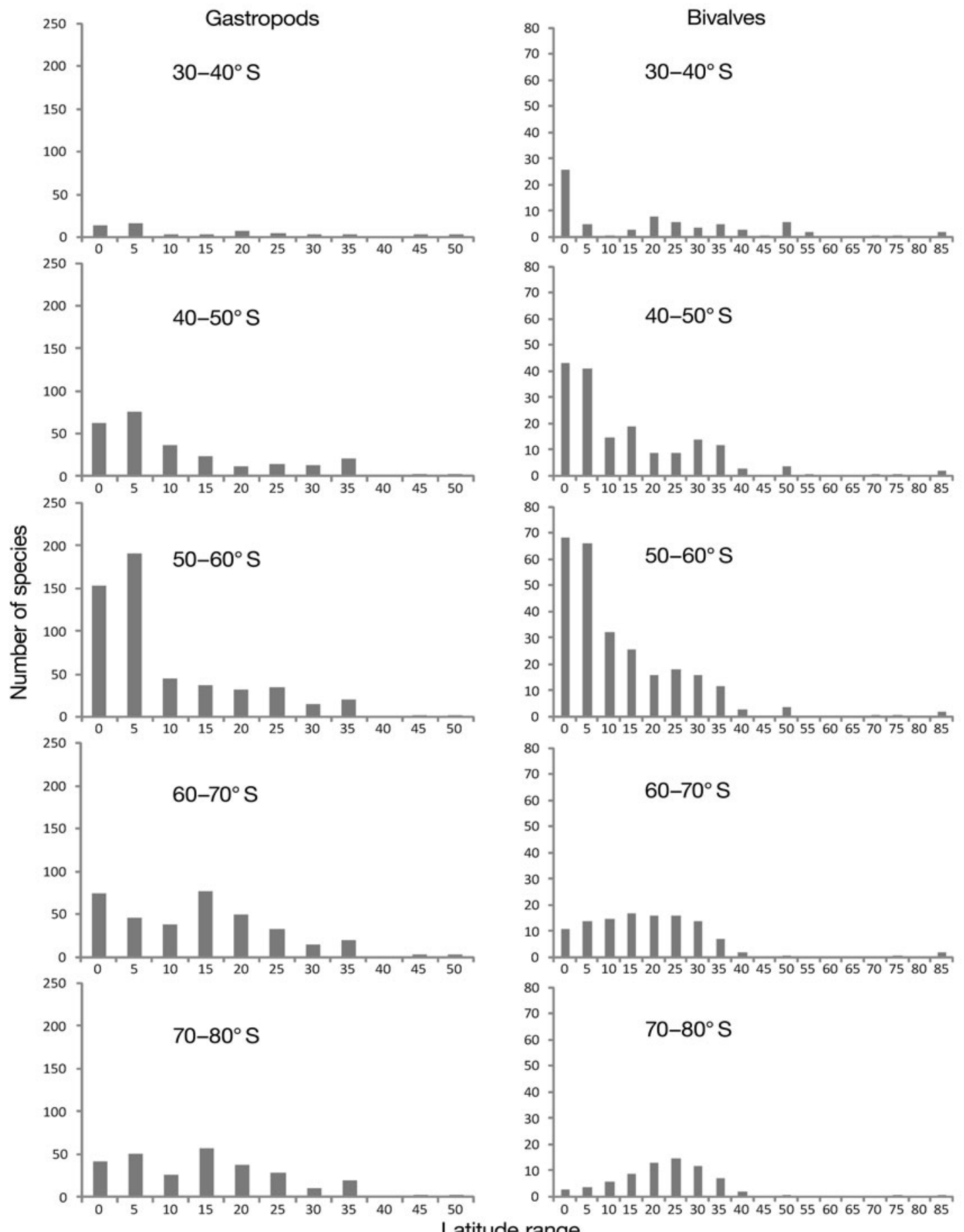

Fig. 6. Range widths of species of gastropod and bivalve molluscs. Numbers of species with range width grouped by $10^{\circ}$ latitude bins. Data from SOMBASE and SCARMarBIN databases 
(a)
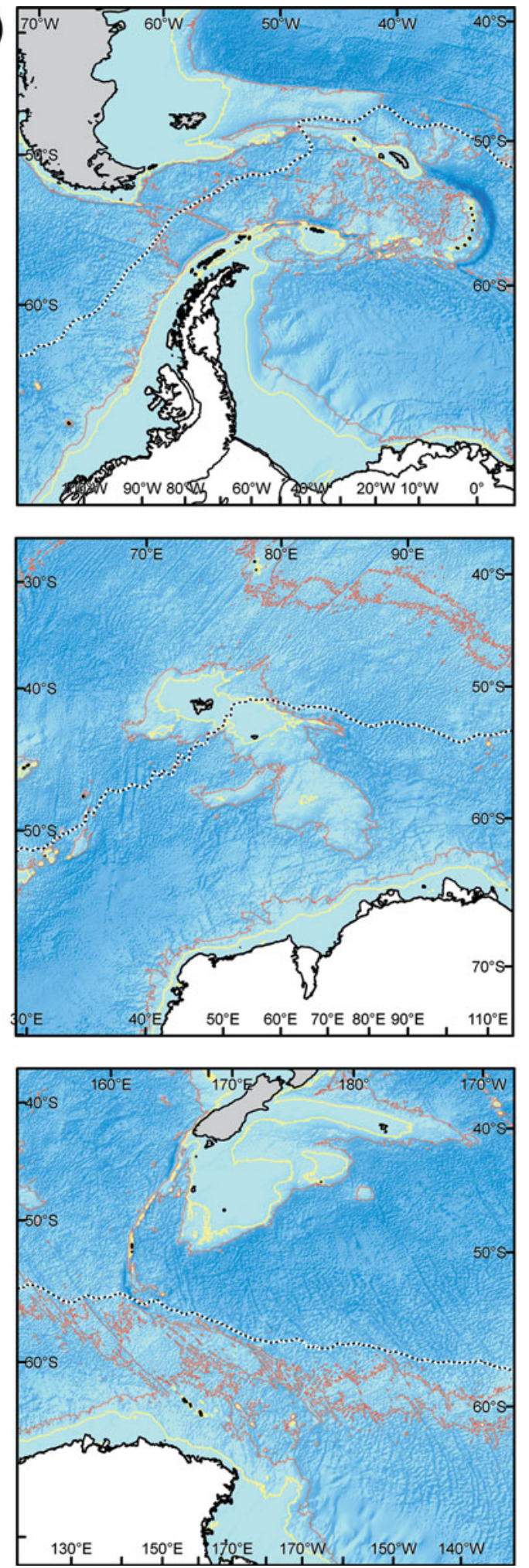

(b)
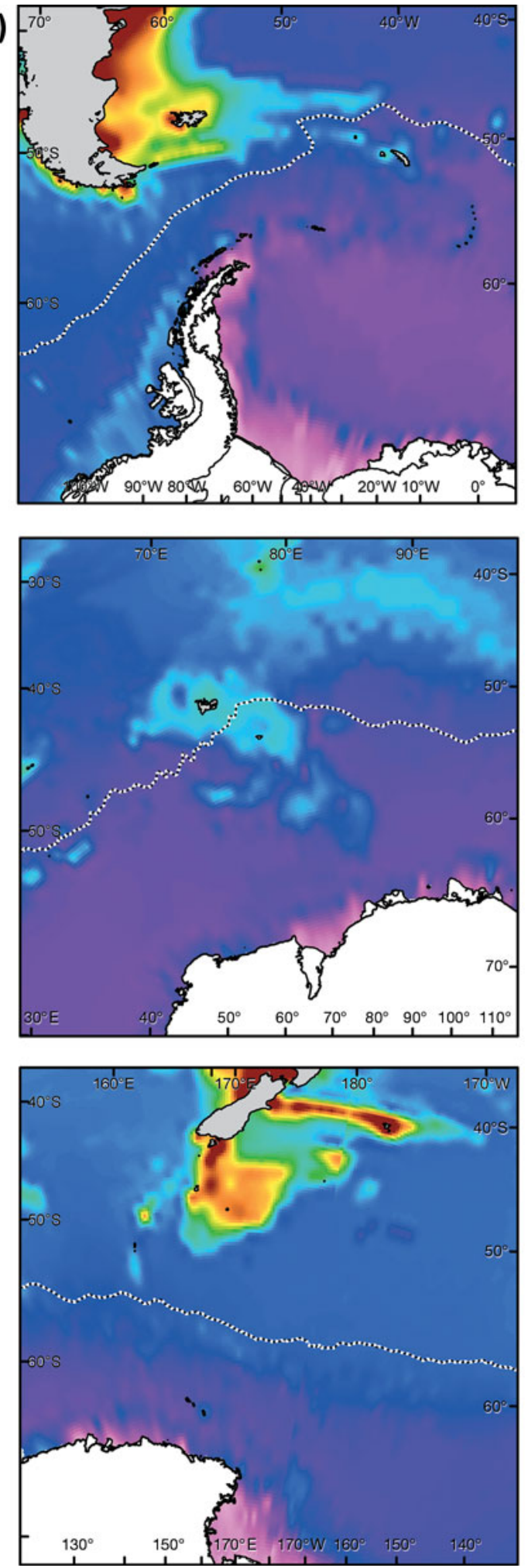

Fig. 7. (a) Bathymetry and (b) seabed temperature of the 3 major regions of linear (north-south aligned) coast around Antarctica. From top to bottom these are the Antarctic Peninsula, the Kerguelen Plateau and Victoria Land (in text as AP, KP and VL respectively). In (a) the 1000 and $3000 \mathrm{~m}$ contours are shown as well as continental shelf areas in light blue. In (b) seabed temperature scale is from negative (light pink) to cool (blues) and warm (green, yellow, orange). Sea temperature data are from Clarke et al. (2009). The dashed line indicates the Polar Front 
reflects a focus on the Antarctic for this dataset). Amongst the species at Cape Horn there are likely to be many key potential invaders of the $\mathrm{SO}$, and probably only the lack of continuous shelf, the abrupt oceanographic change at the $\mathrm{PF}$, and the direction of the currents prevent southward range spread as invaders. The Scotia arc may act as stepping-stones south for plants, terrestrial invertebrates and microbes through dispersal on extreme wind events (Marshall 1996) as well as for birds, but genetic evidence to date suggests benthos disperses from the Antarctic Peninsula out to the Scotia arc, rather than vice versa (e.g. Linse et al. 2007). Marine organisms may disperse southwards as larvae in mesoscale eddies or in ship ballast water, or as adults on debris or ship hulls (Lewis et al. 2006) but so far only a few non-indigenous algae seem to have established (Clayton et al. 1997). So the 'bottleneck' of temperate species at their southern limit at Cape Horn (as was expected), is likely to increase as a hotspot as other species migrate southwards from the Patagonian shelf. As the northern limits for different species shift southwards, it is also likely to be the focus point for shrinking range sizes (until a chance event allows species to cross the PF and so establish themselves in the SO). It is likely that a similar situation exists along the South African coast, although only 22 non-indigenous species are currently known there (Griffiths et al. 2009). Adults (e.g. Ralph et al. 1976) and larvae (Thatje \& Fuentes 2003) have travelled into the $\mathrm{SO}$, but have seemingly been unable to complete life-cycles.

True geographic limits for even the more obvious large Antarctic macro- and megafauna are still being established. For example, the BIOPEARL I scientific cruise of 2006 found the hexacorals Balanophyllia malouinensis (in the Falkland Trough) and Flabellum curvatum (at Elephant Island, north Antarctic Peninsula) both south of their previously known southern limit (British Antarctic Survey unpubl. data). Likewise, new southern limits have also been recently established in the region for a number of species in other taxa (e.g. bryozoans: Lopez de la Cuadra \& Garcia Gomez 2000). Despite this, in terms of detecting response to warming, it will be clearly easier to monitor the disappearance of species from a site (i.e. retreating northern limits) than to survey for whichever new species might arrive (i.e. increasing southernmost limits). In areas with well established baselines, such as for terrestrial fauna in Europe, monitoring arrivals of species in new areas is easier (Clay-Jones \& Bignell 2008) but the statistics of detecting first presences is complex. Although our data set was not as strong for investigation of northern range limits, we argue that examination and monitoring of these is more important (than southern limits).
Our second hypothesis was that the present and past boundary of the PF would mark hotspots of northernmost limits. The patterns found in gastropod and bivalve molluscs confirmed this (Fig. 5), as did non-georeferenced data of ascidians, bryozoans and fish (Table 1). The PF has long been suggested to be a major discontinuity, and thus a northern limit for much SO biodiversity (e.g. Ekman 1953). New molecular approaches show that some species with ranges apparently crossing the PF are actually separate cryptic species each side (Hunter \& Halanych 2008). Only 3 shelf areas are just south (one grid box in the methods reported here) of the $\mathrm{PF}$, South Georgia, Bouvet and Heard islands. Of these only South Georgia is both old and large (so should be biodiverse), which explains it emerging as a strong hotspot of northernmost limits (Fig. 5, Table 1). Hotspots of northern limits of SO fauna north of the $\mathrm{PF}$, such as at $\mathrm{KP}$, reflect that the $\mathrm{PF}$ regularly wanders north of sub-Antarctic islands (Moore et al. 1999) or is permanently north during glaciations (Frank et al. 2000).

The main question posed by the current study was where to concentrate effort to detect responses in biodiversity to projected southern polar warming. The current study suggests 2 key areas are most appropriate for monitoring marine benthic response to warming: South Georgia and Kerguelen. This is mainly because the data showed them to be the strongest hotspots for southern and northern range limits across taxa (Table 1, Figs. 2,4,5). The proximity of a marine biological research station and the presence of a discrete shelf should make detecting the disappearance or appearance of species easier at South Georgia. In contrast, Kerguelen is the only major shelf area which crosses the PF or which has a strong thermal gradient (Fig. 7). Other criteria for site suitability include how well the local fauna is known and where invaders are most likely to arrive (see Supplement).

Establishment of sites to focus attention and surveys at (where to look) is clearly a crucial first step, after which the 'what to look at' seems most important as neither the taxonomic expertise nor the effort is available to consider all taxa, or even all species within a given taxon. Irrespective of whether the taxa selected here are or are not the most sensitive indicator taxa, they are currently amongst the best taxa to monitor for response to change on the basis of their having the most geographic and bathymetric information available. At local scale this will differ with site: for example data from this study showed that ophiuroid data was the strongest for the Kerguelen region, but poorest for Cape Horn. Specific species, which are listed here with range edges at South Georgia, include some (in bold in Table 1) which have many 'indicator' characteristics (such as being common, abundant, presence in shal- 
lows and at known sites, and ease of recognition). Furthermore some of these potential model species for monitoring of range change have been widely studied internationally as model Antarctic benthic organisms (e.g. Laternula elliptica), and some of these have already been established as very thermally sensitive at the edge of their range (e.g. Nacella concinna, Morley et al. 2009). Some detail is known for some of the suggested indicator species (e.g. depth ranges and thermal biology: see Supplement).

Finally we considered the range sizes (rather than range limits) of southern polar benthos because of the linkage to past survival success during times of environmental change (Roy et al. 2001), but also because, like (and partly because of) limit shifts, we expect these to change with warming. The smaller latitudinal ranges, which found in gastropod and bivalves at lower latitudes (Fig. 6) may be due to differing rate of temperature change with latitude (Fig. 8). Sea temperature increases $3.34^{\circ} \mathrm{C}$ with each $10^{\circ}$ decrease in latitude north of $55^{\circ} \mathrm{S}$. Mean sea temperature only decreases $0.76^{\circ} \mathrm{C}$ with each $10^{\circ}$ latitude south of $55^{\circ} \mathrm{S}$. Temperature is not the only variable that changes less at higher southern latitudes (salinity would be another example), and thus larger geographic range sizes at higher latitudes may simply reflect greater similarity of environmental conditions. Bivalves showed a stronger pattern than gastropods because they tend to be wider ranging (Clarke et al. 2007) whereas gastropods tend to be more endemic to small areas (Linse et al. 2006). Bivalves may thus be amongst the best taxa to watch with respect to SO invasion (e.g. see Ralph et al. 1976). With a southern limit hotspot at Cape Horn, the sites most visited by ships (such as Deception I) will be amongst the most likely places for bivalve invaders to arrive.

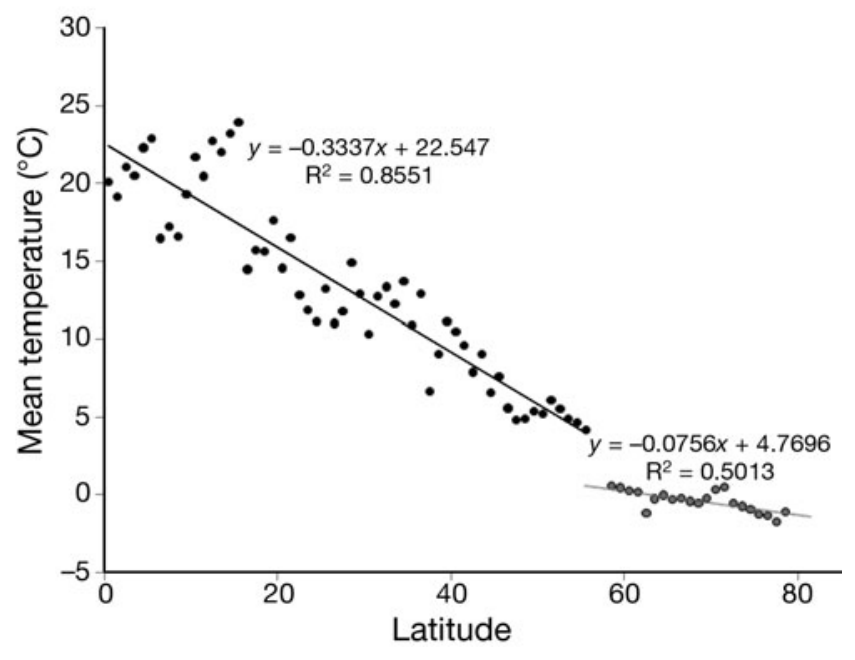

Fig. 8. Mean temperature for the sea floor down to $1000 \mathrm{~m}$ for each latitudinal band (data from Clarke et al. 2009)

\section{CONCLUSIONS}

Most of Antarctica's biodiversity occurs on the continental shelf, and the most likely response to rapid warming is by species changing their ranges. The quality and quantity of data are much better for some areas and taxa than others, and both of these have been highlighted here; this information is within openly-accessible databases (such as SCAR-MarBIN). Range shifts of Antarctic marine benthic species will not necessarily be along continental shelf areas aligned N-S because temperature does not always decrease southwards along them and, apart from the Kerguelen Plateau, they have no continuity with cool temperate areas. The current paper, the first account of baselines of northern and southernmost limits of Antarctic taxa, shows that Cape Horn is a range limit hotspot and bottleneck for southernmost species, and thus potential alien invaders. We suggest that South Georgia and the Kerguelen Plateau are amongst the best areas to monitor range shifts for a variety of reasons, but in both cases it is likely that detecting shrinking northernmost limits will be easier to achieve and to test potential predictive models with. Bivalves seem to be a good candidate group to use as indicators but there are a number of key species across a variety of classes which fulfil major criteria, such as being easily identifiable, common and abundant. Because of strong bathymetric temperature gradients at both of these localities, bathymetric migration seems at least as likely as geographic migration given the supposedly high level of eurybathy in Antarctic shelf taxa.

Acknowledgements. Stefanie Kaiser was able to participate in this work thanks to a grant (DAAD and DFG, contract No Br 1121/26-2-4). We thank 3 anonymous referees and the editor Alain Vézina for comments leading to a much improved manuscript.

\section{LITERATURE CITED}

Ahlstrom D, Napper E (2002) Antarctic species face extinction threat. The Irish Times, Dublin, 10th September.

Arntz WE, Brey T, Gallardo VA (1994) Antarctic zoobenthos. Oceanogr Mar Biol Annu Rev 32:241-304

> Aronson RB, Moody RM, Ivany LC, Blake DB, Werner JE, Glass A (2009) Climate change and trophic response of the Antarctic bottom fauna. PLoS One 4:e4385

Bamber JL, Riva REM, Vermeersen BLA, LeBrocq AM (2009) Reassessment of the Potential Sea-Level Rise from a Collapse of the West Antarctic Ice Sheet. Science 324: 901-903

Barnes DKA, Peck LS (2008) Vulnerability of Antarctic shelf biodiversity to predicted climate change. Clim Res 37: 149-163

Barnes DKA, Fuentes V, Clarke A, Schloss IR, Wallace M (2006) Spatial and temporal variation in shallow seawater temperatures around Antarctica. Deep-Sea Res II 53:853-865 
Barnes DKA, Kaiser S, Griffiths HJ, Linse K (2009) Marine, intertidal, freshwater and terrestrial biodiversity of an isolated polar archipelago. J Biogeogr 36:756-769

Beaugrand G, Reid PC, Ibanez F, Lindley JA, Edwards M (2002) Reorganization of North Atlantic marine copepod biodiversity and climate. Science 296:1692-1694

Brandt A, Gooday AJ, Brandao SN, Brix S and others (2007) First insights into the biodiversity and biogeography of the Southern Ocean deep sea. Nature 447:307-311

Brooker RW, Travis JMJ, Clark EJ, Dytham C (2007) Modelling species' range shifts in a changing climate: The impacts of biotic interactions, dispersal distance and the rate of climate change. J Theor Biol 245:59-65

Clarke A, Johnston NM (2003) Antarctic marine benthic diversity. Oceanogr Mar Biol Annu Rev 41:47-114

> Clarke A, Griffiths HJ, Linse K, Barnes DKA, Crame A (2007) How well do we know the Antarctic marine fauna? A preliminary study of macroecological and biogeographical patterns in Southern Ocean gastropod and bivalve molluscs. Divers Distrib 13:620-632

- Clarke A, Griffiths HJ, Barnes DKA, Meredith MP, Grant S (2009) Spatial variation in seabed temperatures in the Southern Ocean: implications for benthic ecology and biogeography. J Geophys Res G, 3003, doi:10:1029/2008 JG000886

Clay-Jones M, Bignell P (2008) Invasion of the aliens. In: The Independent, 31/08/2008, London, p 24-25

> Clayton MN, Wiencke C, Klöser H (1997) New records and sub-Antarctic marine benthic macroalgae from Antarctica. Polar Biol 17:141-149

DeBroyer C, Danis B (eds) (2008). SCAR-MarBIN: The Antarctic Marine Biodiversity Information Network. Available online at www.scarmarbin.be/ [accessed July 2008]

Ekman S (1953) Zoogeography of the sea. Sidgwick and Jackson, London.

Frank M, Gersonde R, Rutgers van der Loeff MM, Bohrmann G and others (2000) Similar glacial and interglacial productivity in the Atlantic sector of the Southern Ocean: Multiproxy evidence and implications for glacial atmospheric $\mathrm{CO}_{2}$. Paleoceanography 15:642-658

> Griffiths HJ, Linse K, Crame AJ (2003) SOMBASE - Southern Ocean Mollusc Database: A tool for biogeographic analysis in diversity and ecology. Org Divers Evol 3:207-213

Griffiths CL, Robinson TB, Mead A (2009) The status and distribution of marine alien species in South Africa. In: Rilov G, Crooks JA (eds) Biological invasions in marine ecosystems, Chap 23. Ecological, management and geographic perspectives. Ecological Studies, 204. Springer, Berlin

Hunter RL, Halanych KM (2008) Estimating connectivity in the brooding brittle star Astrotoma agassizii across the Drake Passage in the Southern Ocean. J Hered 99:137-148

> Lewis PN, Bergstrom DM, Whinam J (2006) Barging in: a temperate marine community travels to the subantarctic. Biol Invasions 8:787-795

Lima FP, Ribeiro PA, Queiroz N, Xavier R, Tarroso P, Hawkins S, Santos AM (2007) Modelling past and present geographical distribution of the marine gastropod Patella rustica as a tool for exploring responses to environmental change. Glob Change Biol 13:2065-2077

Linse K, Griffiths HJ, Barnes DKA, Clarke A (2006) Biodiversity and biogeography of Antarctic and Sub-Antarctic Mollusca. Deep-Sea Res II 53:985-1008

Linse K, Cope T, Lörz AN, Sands C (2007) Is the Scotia Sea a centre of Antarctic marine diversification? Some evidence of cryptic speciation in the circum-Antarctic bivalve Lis- sarca notocardensis (Arcoidea: Philopbryidae). Polar Biol 30:1059-1068

Lopez de la Cuadra CM, Garcia Gomez JC (2000) The Cheilostomate Bryozoa (Bryozoa: Cheilostomatida) collected by the Spanish 'Antártida 8611' expedition to the Scotia Arc and South Shetland Islands. J Nat Hist 34: 755-772

Marshall WA (1996) Biological particles over Antarctica. Nature 24:383

Meredith MP, King JC (2005) Rapid climate change in the ocean west of the Antarctic Peninsula during the second half of the 20th century. Geophys Res Lett 32:L19604, doi: 10.1029/2005GL024042

> Mieszkowska N, Hawkins SJ, Burrows MT, Kendall MA (2007) Long-term changes in the geographic distribution and population structures of Osilinus lineatus (Gastropoda: Trochidae) in Britain and Ireland. J Mar Biol Assoc UK 87:537-545

Moore JK, Abbott MR, Richman JG (1999) Location and dynamics of the Antarctic Polar Front from satellite sea surface temperature data. J Geophys Res 104:3059-3073

Morley SA, Hirse T, Portner HO, Peck LS (2009) Geographical variation in thermal tolerance within Southern Ocean marine ectotherms. Comp Biochem Physiol 153:154-161

> Peck LS (2005) Prospects for surviving climate change in Antarctic aquatic species. Front Zool 2:9

> Poloczanska ES, Hawkins SJ, Southward AJ, Burrows MT (2008) Modelling the response of populations of competing species to climate change. Ecology 89:3138-3149

> Poulin E, Palma AT, Féra JP (2002) Evolutionary versus ecological success in Antarctic benthic invertebrates. Trends Ecol Evol 17:218-222

Ralph R, Maxwell JGH, Everson I, Hall J (1976) A record of Mytilus edulis L. from South Georgia. Br Antarct Surv Bull 44:101-102

> Riddle MJ, Craven M, Goldsworthy PM, Carsey F (2007) A diverse benthic assemblage $100 \mathrm{~km}$ from open water under the Amery Ice Shelf, Antarctica. Paleoceanography 22:PA1204. doi:10.1029/2006PA001327

Roy K, Jablonski D, Valentine JW (2001) Climate change, species range limits and body size in marine bivalves. Ecol Lett 4:366-370

Somero GN, DeVries AL (1967) Temperature tolerance of some Antarctic fishes. Science 156:257-258

Thatje S, Fuentes V (2003) First record of anomuran and brachyuran larvae (Crustacea: Decapoda) from Antarctic waters. Polar Biol 26:279-282

> Thomas CD, Lennon JL (1999) Birds extend their ranges northwards. Nature 399:213

Thomas CD, Cameron A, Green RE, Bakkenes M and others (2004) Extinction risk from climate change. Nature 427: $145-148$

Vaughan DG, Marshall GJ, Connolley WM, Parkinson C and others (2003) Recent rapid regional climate warming on the Antarctic Peninsula. Clim Change 60:243-274

Whitehouse MJ, Meredith MP, Rothery P, Atkinson A, Ward P, Korb RE (2008) Rapid warming of the ocean around South Georgia, Southern Ocean, during the $20^{\text {th }}$ Century: Forcings, characteristics and implications for lower trophic levels. Deep-Sea Res I 55:1218-1228

Zachos J, Pagani M, Sloan L, Thomas E, Billups K (2001) Trends, rhythms and aberrations in global climate $65 \mathrm{Ma}$ to present. Science 292:686-693

> Zwally HJ, Comiso JC, Parkinson CL, Cavalieri DJ, Gloersen P (2002) Variability of Antarctic sea ice 1979-1998. J Geophys Res 107, 3041. doi:10.1029/2000JC000733 